This is the Accepted Version of a forthcoming article that will be published by

Oxford University Press in Journal of International Criminal Justice:

http://iicj.oxfordjournals.org/content/by/year

Accepted Version downloaded from SOAS Research Online:

http://eprints.soas.ac.uk/22524/

\title{
RADICAL COMPLEMENTARITY
}

\author{
Kevin Jon Heller*
}

\section{INTRODUCTION}

In October 2011, the ICC's Pre-Trial Chamber (PTC) authorised the Office of the Prosecutor (OTP) to open an investigation into Côte d'Ivoire's 2010 and 2001 post-election violence. ${ }^{1}$ Over the next four months, the PTC issued arrest warrants for the deposed President of Côte d'Ivoire, Laurent Gbagbo, his First Lady, Simone Gbagbo, and Charles Blé Goudé, one of the Gbagbos' closest political allies. Côte d'Ivoire formally surrendered Laurent and Blé Goudé to the Court, but later refused to surrender Simone on the ground that it intended to prosecute her domestically. ${ }^{2}$ Simone Gbagbo's trial began in an Abidjan court in December 2014; in March 2015, Gbagbo ${ }^{3}$ was convicted on all counts and sentenced to 20 years imprisonment - double the sentence requested by the prosecution. 4

At first glance, Simone Gbagbo's trial in Côte d'Ivoire seems to represent a major victory for the principle of complementarity, the idea that the Court and States should work in unison - by complementing each other - in reaching the Statute's overall goal... to fight against impunity'. ${ }^{5}$ The ICC

* Professor of Criminal Law, SOAS, University of London. My thanks to Nastasia Bach for her typically superb research assistance.

1 Warrant of Arrest for Simone Gbagbo, Simone Gbagbo (ICC-02/11-01/12), Pre-Trial Chamber III, 29 Feb. 2012, § 1 (Gbagbo Arrest Warrant).

2 Decision on Côte d'Ivoire's challenge to the admissibility of the case against Simone Gbagbo, Simone Gbagbo (ICC-02/11-01/12), Pre-Trial Chamber I, 11 Dec. 2014, § 3 (Gbagbo Admissibility Decision).

${ }^{3}$ For sake of readability, this article will generally refer to Simone Gbagbo as 'Gbagbo'. It will refer to 'Laurent Gbagbo' when necessary.

4 M. Caldwell, 'Ivorians Divided Over Simone Gbagbo Conviction', dw.com, 10 Mar. 2015, available online at http://www.dw.com/en/ivorians-dividedover-simone-gbagbo-conviction/a-18305986.

5 Dissenting Opinion of Judge Anita Uŝacka, Judgment on the appeal of Libya against the decision of Pre-Trial Chamber I of 31 May 2013 entitled 'Decision on the admissibility of the case against Saif Al-Islam Gaddafi', Gaddafi and Al- 
announced its intention to prosecute Gbagbo; Côte d'Ivoire asserted its right to prosecute her itself; a domestic trial took place; and Gbagbo was ultimately given a sentence considerably longer than any sentence the ICC has imposed to date.

Looks, however, can be deceiving: whereas the OTP intended to prosecute Simone Gbagbo for the crimes against humanity of murder, rape, other inhumane acts, and persecution, ${ }^{6}$ the Ivorian court convicted her for ordinary domestic crimes such as disturbing the peace, organising armed gangs, and undermining state security. ${ }^{7}$ The OTP had argued from the beginning of the national proceedings that the Ivorian charges against Gbagbo did not make her case inadmissible, because they were not based on 'substantially the same conduct' as its own charges - the test the Appeals Chamber has adopted to determine whether national and international prosecutions involve the same case, as required by Art. 17(1) of the Rome Statute. ${ }^{8}$ The Pre-Trial Chamber rejected Côte d'Ivoire's admissibility challenge on precisely that ground two weeks before Gbagbo's trial opened in Abidjan, ${ }^{9}$ and the Appeals Chamber upheld the PTC's decision two months after Gbagbo was convicted and sentenced. ${ }^{10}$ Côte d'Ivoire is thus currently obligated to surrender

Senussi (ICC-01/11-01/11-547-Anx2), Appeals Chamber, 21 May 2014, § 57 (Uŝacka Gaddafi Dissent).

6 See Gbagbo Arrest Warrant, supra note 1, § 7.

7 Caldwell, supra note 4. Côte d'Ivoire also charged Gbagbo with economic crimes. The precise nature and status of those charges is unclear. See generally Public redacted version of 'Prosecution's Response to Côte d'Ivoire's Challenge to the admissibility of the case against Simone Gbagbo', Simone Gbagbo (ICC-02/11-01/12), Pre-Trial Chamber I, 24 June 2014.

${ }^{8}$ See Judgment on the appeal of the Republic of Kenya against the decision of Pre-Trial Chamber II of 30 May 2011 entitled 'Decision on the Application by the Government of Kenya Challenging the Admissibility of the Case Pursuant to Article 19(2)(b) of the Statute', Muthaura, Kenyatta, and Ali (ICC01/09-02/11 OA), Appeals Chamber, 30 Aug. 2011, § 39 (Kenyatta Appeals Judgment); Judgment on the appeal of the Republic of Kenya against the decision of Pre-Trial Chamber II of 30 May 2011 entitled 'Decision on the Application by the Government of Kenya Challenging the Admissibility of the Case Pursuant to Article 19(2)(b) of the Statute', Ruto, Kosgey, and Sang (ICC01/09-01/11 OA), Appeals Chamber, 30 Aug. 2011, § 40 (Ruto Appeals Judgment).

${ }^{9}$ See Judgment on the appeal of Côte d'Ivoire against the decision of PreTrial Chamber I of 11 December 2014 entitled 'Decision on Côte d'Ivoire's challenge to the admissibility of the case against Simone Gbagbo', Simone Gbagbo (ICC-02/11-01/12 OA), Appeals Chamber, 27 May 2015, § 14 (Gbagbo Appeals Judgment).

10 Ibid., § 2. 
Gbagbo to the Court, ${ }^{11}$ although it has given no indication that it intends to do so. ${ }^{12}$

The admissibility of Simone Gbagbo's case raises significant questions about the ICC's complementarity jurisprudence. As is well known, Art. 17 of the Rome Statute requires the Court to defer to a national investigation or prosecution of an individual suspected of committing international crimes unless 'the State is unwilling or unable genuinely to carry out the investigation or prosecution' itself. ${ }^{13}$ Art. 17 reflects the object and purpose of the principle of complementarity, which is 'to protect sovereign interests in the pursuit of justice for crimes within the Court's jurisdiction'.14 Indeed, the Rome Statute would never have been adopted had Art. 17 not treated the Court's right to pre-empt a national proceeding as an 'exceptional power'15 to be used sparingly and only as a last resort. ${ }^{16}$

11 Gbagbo Admissibility Decision, supra note 2, § 80 .

12 On the contrary, it has recently initiated announced that it intends to try Simone Gbagbo again - this time ostensibly for crimes against humanity. See A. Aboa, 'Former first leady Simone Gbagbo to face trial in Ivory Coast in April', Reuters, 18 Mar. 2016, available online at http://uk.reuters.com/article/uk-ivorycoast-politics-trial-idUKKCN0WK2CB. The precise allegations remain unclear.

13 Art. 17(1) ICCSt.

14 S.M.H. Nouwen, Complementarity in the Line of Fire: The Catalysing Effect of the International Criminal Court in Uganda and Sudan (Cambridge University Press, 2013) at 58; see also M. Benzing, "The Complementarity Regime of the International Criminal Court: International Criminal Justice Between State Sovereignty and the Fight Against Impunity', 7 Max Planck Yearbook of United Nations Law (2003) 591-632, at 595 (noting that '[t]he most apparent underlying interest that the complementarity regime of the Court is designed to protect is the sovereignty both of State parties and third states').

15 F. Megrét \& M.G. Samson, 'Holding the Line on Complementarity in Libya: The Case for Tolerating Flawed Domestic Trials', 11 Journal of International Criminal Justice (JICJ) (2013) 571-589, at 578; see also M.M. El Zeidy, The Principle of Complementarity in International Criminal Law: Origin, Development and Practice (Martinus Nijhoff, 2008) at 306 (noting that admissibility should exist only in 'exceptional circumstances').

16 P. McAuliffe, 'From Watchdog to Workhorse: Explaining the Emergence of the ICC's Burden-sharing Policy as an Example of Creeping Cosmopolitanism', 13 Chinese Journal of International Law (2014) 259-296, at 273 ('From the earliest stages in the negotiation process, States rejected international primacy on the basis that they had a vital interest in remaining responsible and accountable for prosecuting violations of their laws'.). 
Given Art. 17's emphasis on state sovereignty, it is important to consider whether the Court's decision in Simone Gbagbo is consistent with the principle of complementarity. This Article argues that it is not - that Côte d'Ivoire can be considered 'inactive' under Art. 17 only because the ICC's judges have imposed structural limits on national proceedings that are inconsistent with the Rome Statute and counterproductive in practice. The Article thus defends what we might call 'radical complementarity': the idea that as long as a state is making a genuine effort to bring a suspect to justice, the ICC should find his or her case inadmissible regardless of the conduct the state investigates or the prosecutorial strategy the state pursues.

The Article itself is divided into two sections. Section 1 criticises the Court's jurisprudence concerning Art. 17's 'same person' requirement, arguing that the test the judges use to determine whether a state is investigating a particular suspect is both inconsistent with the Rome Statute and far too restrictive in practice. Section 2 then uses Simone Gbagbo's case to explain why the 'same conduct' requirement is antithetical to the goals underlying complementarity and should be rejected as a matter of law.

\section{THE 'SAME PERSON' REQUIREMENT}

In the Kenya cases, the Appeals Chamber made clear that no admissibility challenge can succeed unless the state is actively investigating the same suspect as the OTP:

The words 'is being investigated', in this context, signify the taking of steps directed at ascertaining whether those suspects are responsible for that conduct, for instance by interviewing witnesses or suspects, collecting documentary evidence, or carrying out forensic analyses. The mere preparedness to take such steps or the investigation of other suspects is not sufficient. This is because unless investigative steps are actually taken in relation to the suspects who are the subject of the proceedings before the Court, it cannot be said that the same case is (currently) under investigation by the Court and by a national jurisdiction, and there is therefore no conflict of jurisdictions. ${ }^{17}$

The critical question, of course, is what kinds of national investigative steps are required to establish that a state is indeed genuinely investigating the suspect targeted by the ICC. The Appeals Chamber has not provided a specific

17 See, e.g., Kenyatta Appeals Judgment, supra note 8, § 40. 
answer to that question, choosing instead to articulate three general principles that govern the inquiry. Two of those principles are addressed to states: (1) a state must 'provide the Court with evidence of a sufficient degree of specificity and probative value that demonstrates that it is indeed investigating the case', because 'it is not sufficient merely to assert that investigations are ongoing'18; and (2) evidence of 'concrete and progressive investigative steps' is required. ${ }^{19}$ The third principle is then addressed to the ICC's judges, directing them not to adopt a view of the investigation requirement that elides the distinction between inactivity and unwillingness:

[D]etermining the existence of an investigation must be distinguished from assessing whether the State is 'unwilling or unable genuinely to carry out the investigation or prosecution', which is the second question to consider when determining the admissibility of a case. For assessing whether the State is indeed investigating, the genuineness of the investigation is not at issue; what is at issue is whether there are investigative steps. ${ }^{20}$

The Appeals Chamber's first and third principles are unobjectionable. Its second principle, however, is problematic. To begin with, the Appeals Chamber simply invented the requirement that investigative steps must be 'progressive' as well as 'concrete'. Art. 17 requires only that '[t]he case is being investigated', which suggests that any investigative step involving the same suspect will satisfy the investigation requirement. Consideration of an investigation's temporal aspects thus seems more appropriately addressed in the Pre-Trial Chamber's assessment of whether the state is genuinely willing to investigate. If a state begins an investigation but does nothing to progress it, it would not be unreasonable for the PTC to infer unwillingness.

The Appeals Chamber's insistence that a state must both initiate and progress an investigation thus does precisely what it told the Pre-Trial Chamber not to do: elide the difference between inactivity and unwillingness. Indeed, Judge Ušacka made precisely that point in her dissent in the Ruto case when she responded to the majority's 'demanding definition' of the investigation requirement. In her view, the majority had 'circumvented' the 'high threshold' the drafters of the Rome State had established for

18 Ibid., §§ 58-61.

${ }^{19}$ Gbagbo Appeals Judgment, supra note 9, § 81; Kenyatta Appeals Judgment, supra note $8, \S 81$.

20 Kenyatta Appeals Judgment, supra note 8, § 40. 
unwillingness by requiring Kenya to prove the existence of 'a full-fledged investigation... in order to establish that there is no situation of inactivity'. ${ }^{21}$

Judge Ušacka's criticism represents an accurate assessment of the Pre-Trial Chamber's insistence that Kenya was inactive regarding the Ocampo Six - a conclusion upheld by the Appeals Chamber. ${ }^{22}$ As she noted in her dissent, although Kenya did not claim that its investigations were 'very advanced' or 'nearly completed', it did submit evidence that investigations of the Ocampo Six were underway at the time of the admissibility challenge. ${ }^{23}$ With regard to Ruto, for example, Kenya's evidence indicated that a case file had been opened and assigned a number; that the case file referred to Ruto as a suspect; and that the case file provided information concerning the scope of the investigation, including the location and time of Ruto's alleged criminal conduct. ${ }^{24}$ Similarly, with regard to the other defendants, Kenya's evidence indicated not only that the Attorney General had formally ordered the Commissioner of Police to open investigations, but also that criminal investigators were locating potential witnesses, reviewing government documents and news reports, following up previous investigative leads, analysing the actions of lower-level suspects to identify potential cooperating witnesses, and visiting various crime scenes. ${ }^{25}$ The PTC nevertheless concluded that Kenya was 'inactive' with regard to the Ocampo Six because it had failed to submit 'information about dates when investigations, if any, have commenced against the three suspects, and whether the suspects were actually questioned or not, and if so, the contents of the police or public prosecutions' reports regarding the questioning'26 - considerations that were clearly relevant to whether Kenya was genuinely investigating, but went far

${ }^{21}$ Dissenting Opinion of Judge Anita Uŝacka, Judgment on the appeal of the Republic of Kenya against the decision of Pre-Trial Chamber II of 30 May 2011 entitled 'Decision on the Application by the Government of Kenya Challenging the Admissibility of the Case Pursuant to Article 19(2)(b) of the Statute', Ruto, Kosgey, and Sang (ICC-01/09-01/11 OA), Appeals Chamber, 20 Sept. 2011, § 27 (Uŝacka Ruto Dissent).

22 Kenyatta Appeals Judgment, supra note 8, § 69.

23 Uŝacka Ruto Dissent, supra note $21, \S 8$.

24 See ibid.

25 Document in Support of the 'Appeal of the Government of Kenya against the Decision on the Application by the Government of Kenya Challenging the Admissibility of the Case Pursuant to Article 19(2)(b) of the Statute', Muthaura, Kenyatta, and Ali (ICC-01/09-02/11), Appeals Chamber, 20 June $2011, \S 5$.

26 Decision on the Application by the Government of Kenya Challenging the Admissibility of the Case Pursuant to Article 19(2)(b) of the Statute, Ruto, Kosgey, and Sang (ICC-01/09-01/11), Pre-Trial Chamber II, 30 May 2011, $\S$ 69 (Ruto Admissibility Decision). 
beyond what was necessary to establish whether Kenya was investigating at all. ${ }^{27}$

The Pre-Trial Chamber even more blatantly elided the distinction between inactivity and unwillingness in the Simone Gbagbo case. Côte d'Ivoire's uncontested evidence made clear that the state had formally initiated an investigation of Gbagbo, ${ }^{28}$ had detained her, ${ }^{29}$ had interrogated her, ${ }^{30}$ had questioned a partie civile about her actions, ${ }^{31}$ and had attempted to collect evidence relevant to her crimes. ${ }^{32}$ The PTC nevertheless concluded that Côte d'Ivoire was inactive regarding her case, because 'the investigative activities undertaken by the domestic authorities are not tangible, concrete and progressive, but, on the contrary, sparse and disparate'. ${ }^{33}$ That conclusion is difficult to defend: although the sparseness and dissimilarity of Côte d'Ivoire's investigative activities might have indicated that the state was unwilling to investigate Gbagbo $^{34}$ or convinced the PTC that Côte d'Ivoire was not investigating 'substantially the same conduct' as the OTP, 35 there is no question that Côte d'Ivoire was actually investigating Gbagbo's case. Indeed, by the time the Appeals Chamber affirmed the Pre-Trial Chamber's decision that Cote d'Ivoire was "inactive" with regard to her case, Gbagbo had already been convicted and sentenced - a perverse outcome made possible by the Appeals Chambers' excessively formalist, and rather guilty, insistence that it had to "exclud[e] facts postdating the Impugned Decision from the scope of its review." 36

Côte d'Ivoire was fully aware that it had not made substantial progress in the investigation at the time of its admissibility challenge. But it did not attribute that lack of progress to either unwillingness or inability - much less to inactivity. Instead, it pointed out that the state had recently emerged from serious conflict and thus lacked the 'considerable material and human

27 The Pre-Trial Chamber also questioned whether Kenya had submitted sufficient evidence to establish that investigations were ongoing. Ibid., § 60 . As Judge Ušacka noted in her dissent, however, the Chamber refused to permit Kenya to submit additional documentation on that issue. Ušacka Ruto Dissent, supra note 21 , § 24.

${ }^{28}$ Gbagbo Admissibility Decision, supra note 2, § 65.

${ }^{29}$ Ibid.

${ }^{30}$ Ibid., $§ 73$.

${ }^{31}$ Ibid., $\S 60$.

32 Ibid., § 72.

33 Ibid., $§ 65$.

34 The PTC consistently emphasised how slowly the investigation was proceeding. See ibid., §§ 68, 69.

35 Which, of course, the Pre-Trial Chamber also concluded. See ibid., § 78.

${ }^{36}$ Gbagbo Appeals Judgment, supra note 9, § 45. 
resources' required to more efficiently investigate a case as complex and politically-charged as Simone Gbagbo's. ${ }^{37}$ The Pre-Trial Chamber ignored that aspect of Côte d'Ivoire's argument, and the Appeals Chamber explicitly dismissed its relevance to the investigation requirement. ${ }^{38}$ That cavalier dismissal illustrates yet another problem with the Appeals Chamber's interpretation of the investigation requirement: it is inherently biased toward states that have not experienced significant conflict and that have well-resourced investigative services - i.e., most states in the Global North. As Judge Ušacka pointed out in her Gaddafi dissent, 'stringent standards' for investigation 'impose unnecessarily high requirements on States with a legal and judicial system in transition and would unduly burden their transitional justice efforts', while 'states that do not have such difficulties [will] more easily meet these high standards'. ${ }^{39}$

The Appeals Chamber's restrictive interpretation of Art. 17's 'same person' requirement also has a significant practical cost: it effectively prohibits a state from relying on the kind of 'pyramidal' prosecutorial strategy that has proven so effective at the ICTY. ${ }^{40}$ As Carla Del Ponte has noted, although all international tribunals are primarily interested in prosecuting those 'most responsible' for international crimes, '[b]uilding a case against the most senior persons responsible may involve a series of cases which "work up the ladder," prosecuting lower-level perpetrators in the collection of evidence against the higher-level perpetrators, or in obtaining the substantive cooperation of insiders'. ${ }^{41}$ Senior political and military leaders rarely leave behind an 'overt trail' of evidence that conclusively connects them to atrocities ${ }^{42}$; a pyramidal strategy may thus be the only effective way to build a case against such perpetrators. Starting with lower-level suspects may also 'provide an opportunity for a court to demonstrate its bona fides in conducting impartial trials' - a critical consideration for many post-conflict states. ${ }^{43}$

Because of these advantages, the Court should avoid finding a state 'inactive' with regard to high-level suspects targeted by the OTP simply because the

37 See, e.g., ibid., § 120.

38 Ibid., § 122.

${ }^{39}$ Uŝacka Gaddafi Dissent, supra note 5, § 62.

${ }^{40}$ C. Del Ponte, 'Investigation and Prosecution of Large-scale Crimes at the International Level: The Experience of the ICTY', 4 JICJ (2006) 539-558, at 545.

41 Ibid. at 543.

42 Ibid. at 544.

43 A.S. Weiner, 'Prudent Politics: The International Criminal Court, International Relations, and Prosecutorial Independence', 12 Washington University Global Studies Law Review (2013) 545-562, at 556-557. 
state is pursuing those suspects through a pyramidal investigative strategy. After all, the OTP itself recently announced its willingness to adopt that kind of strategy:

The required evidentiary standards to prove the criminal responsibility of the most responsible might force the OTP sometimes to change its approach due to limitations on investigative possibilities and/or a lack of cooperation. A strategy of gradually building upwards might then be needed in which the Office first investigates and prosecutes a limited number of mid and high-level perpetrators in order to ultimately have a reasonable prospect of conviction for the most responsible. ${ }^{44}$

Unfortunately, the Appeals Chamber's 'same person' jurisprudence makes it very unlikely the judges will accept a pyramidal investigative strategy - even one specifically designed to build a case against suspects targeted by the OTP. Kenya invoked precisely that kind of 'bottom up' approach in the Kenya cases, arguing that it could not be considered inactive because it had opened formal investigations into the Ocampo Six and intended to develop evidence against them by 'building on the investigation and prosecution of lower level perpetrators'. ${ }^{45}$ Both the Pre-Trial Chamber and the Appeals Chamber rejected Kenya's argument, bizarrely treating it as an 'acknowledgment' by Kenya that 'so far the alleged ongoing investigations have not yet extended to those at the highest level of the hierarchy'. ${ }^{46}$ Neither Chamber explained why prosecuting lower-level suspects in order to convince them to testify against the Ocampo Six could not be considered the kind of 'concrete and progressive investigative steps' ostensibly required by Art. 17.

\section{THE 'SUBSTANTIALLY SAME CONDUCT' REQUIREMENT}

44 ICC Office of the Prosecutor, Strategic Plan June 2012-2015 (2013), at 6, available online at https://www.icccpi.int/en_menus/icc/structure $\% 20$ of $\% 20$ the $\% 20$ court/office $\% 20$ of $\% 20$ th e\%20prosecutor/reports\%20and\%20statements/statement/Documents/0 TP\%20Strategic\%20Plan.pdf.

45 Application on Behalf of the Government of the Republic of Kenya Pursuant to Article 19 of the ICC Statute, Ruto, Kosgey, and Sang \& Muthaura, Kenyatta, and Ali (ICC-01/09-01/11 and ICC-01/09-02/11), Pre-Trial Chamber II, 31 Mar. 2011, § 71 (Kenya Admissibility Challenge).

46 Ruto Admissibility Decision, supra note 26, § 62; Ruto Appeals Judgment, supra note $8, \S 83$. 
The Appeals Chamber applies the 'substantially same conduct' requirement in two different admissibility contexts: (1) when a state challenges the OTP's decision to open a formal investigation into a situation; and (2) when a state or suspect challenges the admissibility of a particular case. In both contexts the requirement is profoundly counterproductive.

\section{A. Situations}

With regard to situations, the key provision in the Rome Statute is Art. 18, which permits states to challenge a decision by the OTP to open an investigation. ${ }^{47}$ When a state challenges the OTP's decision, the OTP must either defer to the national investigation or ask the Pre-Trial Chamber to authorise the investigation over the state's objections. If the OTP pursues the latter course, the PTC must consider admissibility when deciding whether there is a reasonable basis to authorise the investigation. ${ }^{48}$

As the Appeals Chamber has acknowledged, assessing admissibility is very difficult when a state challenges the OTP's decision to investigate a situation. At that point, the OTP is likely to have no more than a preliminary and 'relatively vague' idea of the specific suspects and specific conduct it intends to prosecute. ${ }^{49}$ The Pre-Trial Chamber has thus adopted a relatively general standard for determining whether the state is investigating or prosecuting 'substantially the same conduct' as the ICC:

Accordingly, admissibility at the situation phase should be assessed against certain criteria defining a 'potential case' such as: (i) the groups of persons involved that are likely to be the focus of an investigation for the purpose of shaping the future case(s); and (ii) the crimes within the jurisdiction of the Court allegedly committed during the incidents that are likely to be the focus of an investigation for the purpose of shaping the future case $(\mathrm{s}) \cdot{ }^{50}$

${ }^{47}$ Art. 18(2) ICCSt. The provision applies to both proprio motu investigations and investigations initiated pursuant to a State or Security Council referral.

${ }^{48}$ Art. 53(2) RPE; see also Kenyatta Appeals Judgment, supra note 8, § 37.

49 Kenyatta Appeals Judgment, supra note 8, § 38.

50 Decision Pursuant to Article 15 of the Rome Statute on the Authorization of an Investigation into the Situation in the Republic of Kenya, Situation in the Republic of Kenya (ICC-01/09), Pre-Trial Chamber II, 31 Mar. 2010, § 50 (Kenya Article 15 Decision). 
Although this approach makes intuitive sense, it creates nearly insuperable practical problems for a state that does not want its nationals prosecuted by the Court but is still genuinely committed to bringing the perpetrators of international crimes to justice. Given the length of most preliminary examinations, such a 'willing' state will almost certainly begin national investigations long before the OTP decides to formally investigate the situation. The state will thus be able to forestall a formal OTP investigation only by accurately predicting which conduct ('incidents') the OTP will target if it decides to open an investigation. That is a difficult task at best, given the 'universe of criminality' that characterises situations in which international crimes have been committed. ${ }^{51}$ As Nielsen and Kleffner note, 'the scale of the crimes investigated by international criminal courts' almost always means that the crime base is 'very large, extending over substantial geographic areas and encompassing dozens or even hundreds of individual crime scenes'.52 Even accurately predicting the 0TP's primary suspects will be difficult in that context: as noted earlier, the OTP has recently announced its willingness to prosecute mid-level perpetrators as part of a pyramidal strategy directed towards those 'most responsible' for international crimes, thereby significantly expanding the number of suspects the OTP might target in any particular situation.

It is quite likely, then, that a diligent state that begins national investigations before the OTP intervenes will not focus on all of the same suspects and all of the same conduct as the 0TP. ${ }^{53}$ That state will then face two equallyunpalatable options. The first will be to simply permit the ICC investigation to proceed and wait to challenge the admissibility of specific cases. Few states will accept that option, however, because even the mere opening of an ICC investigation imposes significant reputational costs on a state. ${ }^{54}$ The second option - and thus the lesser of two evils - will be for the state to reconfigure its investigative program to cover the groups of persons and general conduct the OTP identifies in its authorisation request. Wellresourced states may be able to handle such a reconfiguration, even though doing so will still waste investigative resources. Less well-resourced states,

51 R. Rastan, 'What is a 'Case' for the Purpose of the Rome Statute?', 19 Criminal Law Forum (2008) 435-448, at 439.

52 M. Nystedt et al., A Handbook on Assisting International Criminal Investigations (Folke Bernadotte Academy, 2011) at 42; see also M. Konforta \& M.M. Vajda, "The Principle of Complementarity in the Jurisprudence of the ICC', 3 ZPR 3 (2014) 9-27, at 18 (noting that international crimes 'normally encompass a number of different specific incidents or events, as well as a huge number of victims').

53 See Konforta \& Vajda, supra note 52, at 18.

${ }^{54}$ See Nouwen, supra note 14 , at 26. 
by contrast, may either be unable to reconfigure or have to make difficult zero-sum choices concerning which suspects and crimes it will pursue.

Because neither of these two options is desirable, a state that believes the OTP might intervene may simply delay opening national investigations until it knows which suspects and which conduct the OTP intends to investigate. That is an undesirable strategy from the standpoint of combating impunity: in terms of maximising the likelihood of convictions, the earlier a state begins to investigate international crimes, the better. ${ }^{55}$ Moreover, insofar as justice does promote peace - an issue well beyond the scope of this Article delaying national investigations is obviously counterproductive. But it would be a rational strategy nonetheless, precisely because of the SSC requirement.

\section{B. Cases}

The SSC requirement plays an even more critical role when a state (or suspect) challenges the admissibility of a specific case. Here the question is whether a national proceeding 'sufficiently mirrors' the OTP's. ${ }^{56}$ The PreTrial Chambers consistently held that the two proceedings must involve the 'same conduct'. ${ }^{57}$ In the Kenya cases, however, the Appeals Chamber relaxed that requirement, holding that it is enough for a national proceeding to involve 'substantially the same conduct' as the international one. ${ }^{58}$

As Stahn notes, the Appeals Chamber 'failed to explain the origin, meaning, and legal basis of this differentiation'. ${ }^{59}$ The most reasonable interpretation is that it simply believed the 'same conduct' requirement made it too difficult for states to challenge admissibility. That is the OTP's interpretation. ${ }^{60}$ Regardless, the differentiation seems completely unprincipled from the

55 See Nystedt et al., supra note 52, at 64.

56 Judgment on the appeal of Libya against the decision of Pre-Trial Chamber I of 31 May 2013 entitled 'Decision on the admissibility of the case against Saif Al-Islam Gaddafi', Gaddafi and Al-Senussi (CC-01/11-01/11), Appeals Chamber, 21 May 2014, § 73 (Gaddafi Appeals Judgment).

57 See, e.g., Ruto Admissibility Decision, supra note 26, § 55.

58 See, e.g., Kenyatta Appeals Judgment, supra note 8, § 39.

59 C. Stahn, 'Admissibility Challenges before the ICC From Quasi-Primacy to Qualified Deference?' in C. Stahn (ed.), The Law and Practice of the International Criminal Court (Oxford University Press, 2015) 228, at 242.

60 Prosecution's Response to 'Application on behalf of the Government of Libya relating to Abdullah Al-Senussi pursuant to Article 19 of the ICC Statute, Gaddafi and Al-Senussi (ICC-01/11-01/11), Pre-Trial Chamber I, 2 May 2013, § 32 (arguing that "the addition of the word "substantially" introduces a small degree of flexibility into the same conduct test, but not to the point that it undermines the purpose of the test altogether'.). 
standpoint of treaty interpretation. For better or worse, the more restrictive standard has a clear textual basis in the Rome Statute: Art. 20(3), the 'upward' ne bis in idem provision, prohibits the ICC from retrying an individual for the 'same conduct' that was at issue in a previous trial, and Art. 90(1) requires states to notify the Court and the other state whenever it is faced with competing surrender requests involving 'the same conduct'. The 'substantially the same conduct' standard, by contrast, appears nowhere in the Rome Statute. Indeed, Stahn convincingly argues that the Appeals Chamber simply borrowed it from Art. 35(2)(b) of the European Convention on Human Rights, which deals with the admissibility of subsequent applications to the European Court. ${ }^{61}$

In any case, given how the Appeals Chamber has interpreted 'substantially the same conduct', the change is less practically important than it might appear. The Pre-Trial Chamber adopted a quite flexible interpretation of the standard in Al-Senussi, rejecting the OTP's insistence that the national and international investigations must focus on substantially the same incidents in favor of a more holistic comparison between the two investigations' 'temporal, geographic and material parameters'. ${ }^{62}$ In Gaddafi, however, the Appeals Chamber specifically adopted an incident-based comparator for the SSC requirement:

If, and perhaps most straightforwardly, the underlying incidents that the Prosecutor and the State are investigating are identical, the case will be inadmissible before the Court (subject to any finding of unwillingness or inability). At the other end of the scale, the Appeals Chamber finds it hard to envisage a situation in which the Prosecutor and a State can be said to be investigating the same case in circumstances in which they are not investigating any of the same underlying incidents. The real issue is, therefore, the degree of overlap required as between the incidents being investigated by the Prosecutor and those being investigated by a State - with the focus being upon whether the conduct is substantially the same. Again, this will depend upon the facts of the individual case. ${ }^{63}$

61 Stahn, Quasi-Primacy, supra note 59, at 242.

62 Decision on the admissibility of the case against Abdullah Al-Senussi, Gaddafi and Al-Senussi (ICC-01/11-01/11), Pre-Trial Chamber I, 11 Oct. 2013, $\S 75$ (Al-Senussi Admissibility Decision).

${ }^{63}$ Gaddafi Appeals Judgment, supra note 56, § 72. 
To be sure, even with this interpretation the 'substantially the same conduct' requirement is less restrictive than the 'same conduct' requirement. But it still imposes significant and unjustifiable costs on both states and the ICC.

\section{Primacy}

The fundamental problem with the SSC requirement is that it is simply inconsistent with the principle of complementarity. As noted earlier, the object and purpose of the principle is 'to protect sovereign interests in the pursuit of justice for crimes within the Court's jurisdiction'.64 That is why states insisted that the Court's right to pre-empt a national proceeding must be an 'exceptional power', one it can exercise only when a state is unwilling or unable to genuinely investigate or prosecute. The SSC requirement, however, makes admissibility the norm, not the exception: a state can ensure the inadmissibility of a particular case only by deferring to the OTP's choice of incidents to investigate. Any substantial deviation, no matter how justifiable, will render the case admissible. ${ }^{65}$

Even worse, the SSC requirement forces states to constantly predict which incidents the OTP will ultimately decide to prosecute, because those incidents are subject to change until the beginning of trial. The relevant incidents will first be identified in the OTP's request to authorise an investigation, but that request is, for obvious reasons, 'preliminary in nature and is not binding for future admissibility assessments'. ${ }^{66}$ The incidents will then be specified in more detail in the arrest warrant or summons for a specific suspect, but Art. 61(4) of the Rome Statute gives the OTP the absolute right to 'continue the investigation and amend... any charges' until the confirmation of charges hearing. And not even the incidents in the confirmed charges are necessarily final: pursuant to Art. 61(9), '[a]fter the charges are confirmed and before the trial has begun, the Prosecutor may,

64 Nouwen, supra note 14, at 58.

65 See, e.g., Stahn, Quasi-Primacy, supra note 59, at 243 ('The method of comparison promoted by the Appeals Chamber makes it difficult for states to challenge admissibility. It pays little attention to whether and how broader goals of international justice are achieved, since it largely excludes goals and context from the assessment'.); Nouwen, supra note 14, at 58-59 ('This approach does not recognise, and does not want to recognise, that a state that has genuinely investigated or prosecuted that person for different conduct or for different incidents, possibly more serious ones, may have a legitimate interest in guaranteeing that he or she will not be tried before an international tribunal after a domestic trial'.).

${ }^{66}$ Kenya Article 15 Decision, supra note 50, § 50. 
with the permission of the Pre-Trial Chamber and after notice to the accused, amend the charges' ${ }^{67}$

In practice, then, the SSC requirement encourages a state to wait until the eve of trial to challenge admissibility ${ }^{68}$ - a result completely at odds with Art. 19(5)'s insistence that a state 'shall make a challenge at the earliest opportunity'. If the state does not wait until the eve of trial, a successful admissibility challenge could easily prove to be a pyrrhic victory: the OTP can simply request a review of the Court's decision on the ground that 'new facts have arisen' that dictate prosecuting different incidents than those at issue in the admissibility challenge. ${ }^{69}$ The state would then presumably be entitled to file a second admissibility challenge pursuant to Art. 19(4), but it would need the Court's permission to do so. And, of course, that second challenge would succeed only if the state was able to demonstrate prior to trial that it had taken 'concrete and progressive investigative steps' regarding the OTP's amended incidents, because that is the latest a state can challenge admissibility on grounds other than ne bis in idem..$^{70}$ If the state was too slow, its challenge would fail the SSC requirement and it would be deemed 'inactive' in the case.

The SSC requirement, in short, means that states are completely at the mercy of the OTP. If the OTP is sufficiently committed to prosecuting a suspect itself, it will almost always be able to do so. This is not complementarity - it is primacy. ${ }^{71}$ As McAuliffe says, because of the SSC requirement, 'the watchdog function has slipped in the hierarchy as the Court rejects a monitoring role in favour of assuming the prosecutorial and judicial initiative in a manner characteristic of a more vertical relationship'. ${ }^{72}$ For that reason alone the requirement should be eliminated.

\section{Likelihood of Conviction}

67 A new confirmation of charges hearing must be held, of course, if the amendments add new charges or substitute more serious charges. Art. 61(9) ICCSt.

68 As specifically permitted by Art. 19(4) ICCSt. See also Stahn, QuasiPrimacy, supra note 59, at 247.

${ }^{69}$ Art. 17(10) ICCSt.

${ }^{70}$ Art. 19(4) ICCSt.

71 See Ušacka Gaddafi Dissent, supra note 5, § 52 ('Instead of complementing each other, the relationship between the Court and the State would be competitive, requiring the State to do its utmost to fulfill the requirements set by the Court'.).

72 McAuliffe, supra note 16, at 261. 
Although many considerations influence how a national prosecutor uses his or her discretion, the most important is whether a particular prosecution is likely to result in conviction. ${ }^{73}$ No matter how well intentioned, an acquittal has no expressive value and wastes valuable investigative, prosecutorial, and judicial resources. ${ }^{74}$ An acquittal can even undermine the legitimacy of the national criminal-justice system itself. As Concannon notes, pointing to Haiti as an example, '[f]or a transitional government trying to consolidate democracy, especially one having mixed success, prominent human rights trials pose significant political, social, and security risks. If the trial is not successful, the government loses credibility and confidence in the justice system is further eroded, thus creating another flash point for criticism' ${ }^{75}$

In some situations, a state may be able to prosecute substantially the same conduct as the ICC no less effectively than it could prosecute different conduct - especially now that the Appeals Chamber has made clear that the principle of complementarity permits states to charge suspects with ordinary domestic crimes instead of international crimes. ${ }^{76}$ For a variety of reasons, though, there will be many situations in which a prosecution based on different conduct will be much more likely to succeed than one based on the same conduct. In those situations, the Appeals Chamber's mechanical insistence on using the SSC requirement to determine whether a state is 'active' is both counterproductive and indefensible.

\section{a. Investigation}

73 See, e.g., D.D. Ntanda Nsereko, 'Prosecutorial Discretion Before National Courts and International Tribunals', 3 JICJ (2004) 124-144, at 131 (noting that it would not be in the public interest to commence proceedings 'where the evidence is weak and the prospects of a conviction remote').

74 Ibid.

75 B. Concannon, Jr., 'Beyond Complementarity: The International Criminal Court and National Prosecutions, a View from Haiti', 32 Columbia Human Rights Law Review (2000) 201-250, at 235.

76 See Judgment on the appeal of $\mathrm{Mr}$ Abdullah Al-Senussi against the decision of Pre-Trial Chamber I of 11 October 2013 entitled 'Decision on the admissibility of the case against Abdullah Al-Senussi', Gaddafi and Al-Senussi (ICC-OI/II-OI/II OA 6), Appeals Chamber, 24 July 2014, § 119 (Al-Senussi Appeals Judgment) (noting with regard to complementarity that "there is no requirement in the Statute for a crime to be prosecuted as an international crime domestically," because "it is the alleged conduct, as opposed to its legal characterisation, that matters"). 
No prosecution can hope to succeed unless the authorities are able to develop the necessary evidence against the suspect. ${ }^{77}$ The SSC requirement thus implicitly assumes that proving the criminal conduct targeted by the OTP will be no more difficult than proving unrelated criminal conduct. But that will not always be true, for a variety of reasons:

- Availability of Evidence. The OTP's case might require scarce and fragmentary forensic evidence, while the state's preferred case could be proven through easily obtained documentary evidence. Or the OTP's case might require investigating a territorial area that is still experiencing conflict, while the state's preferred case involves an area under complete government control. ${ }^{78}$

- Reliability of evidence. The OTP's case might require eyewitness testimony, which is notoriously unreliable, ${ }^{79}$ while the state's preferred case could be proven solely through forensic evidence that is nearly impossible to discredit.

- Complexity of evidence. The OTP's case might be based on forensic evidence that requires expert investigators and access to specialised scientific equipment, while the state's preferred case could be proven solely through documentary evidence. Or the OTP's case might require complicated statistical analysis of a large number of documents, while the state's preferred case requires only eyewitness testimony.

These hypothetical examples could be multiplied indefinitely. The point is simply that, from an evidential standpoint, there will be many situations in which a state will be better off investigating conduct that does not satisfy the

77 See, e.g., P.C. Stenning, 'Discretion, Politics, and the Public Interest in 'HighProfile' Criminal Investigations and Prosecutions', Canadian Journal of Law and Society (2009) 337-366, at 337 (noting that 'police and prosecutorial resources not being infinite, the investigator or prosecutor must decide whether there is enough evidence, or potential evidence, to justify an investigation or prosecution').

78 See M.B. Harmon \& F. Gaynor, 'Prosecuting Massive Crimes with Primitive Tools: Three Difficulties Encountered by Prosecutors in International Criminal Proceedings', 2 JICJ (2004) 403-426, at 406 ('Investigating a crime in an area in which armed conflict still rages or has recently terminated is obviously logistically more complicated than investigating a crime in times of domestic tranquility'.).

${ }^{79}$ X.A. Aranburu, 'Methodology for Criminal Investigation of International Crimes', in A. Smeulers (ed.), Collective Violence and International Criminal Justice: an Interdisciplinary Approach (Intersentia, 2010) 353, at 367. 
SSC requirement - what we might call the 'Al Capone Effect'. ${ }^{80}$ In such a situation, as long as there is no reason to believe the state is trying to shield the suspect from criminal responsibility, the state should be permitted to investigate the different conduct without the case becoming admissible.

To be sure, this conclusion assumes states are generally better able than the OTP to identify which conduct can be most effectively investigated. But that is a safe assumption, given the OTP's limited resources. Because of its lack of resources, the OTP has traditionally been forced to pursue a policy of 'focused investigations' 81 that last only a few months and address 'as few witnesses and incidents as possible'.82 Those investigations involve small teams of rotating investigators - a maximum of 12 for the entire DRC situation, for example ${ }^{83}$ - and limit the investigators to no more than a few short-term missions, which means that they spend 'relatively little time in the field'. ${ }^{84}$ Indeed, the number of staff allocated to investigative teams actually declined between 2007 and 2013, no doubt reflecting the increase in the number of situations the OTP was investigating. ${ }^{85}$

Lean staffing and short-term missions are clearly cost-effective, but they are antithetical to thorough investigation. HRW has claimed that there are 'simply not enough [investigators] to handle the rigorous demands for

80 Capone was convicted of tax evasion, even though the US government would have preferred to prosecute him murder. The FBI was simply unable to connect him to any of the murders for which he was almost certainly responsible.

81 C.M. De Vos, 'Investigating from Afar: The ICC's Evidence Problem', 26 Leiden Journal of International Law (2013) 1009-1024, at 1014.

82 This according to a former head of the OTP's Jurisdiction, Complementarity, and Cooperation Division. See K. Glassborow, 'ICC Investigative Strategy on Sexual Violence Crimes under Fire', Institute for War \& Peace Reporting, 27 October 2008, available online at http://iwpr.net/report-news/icc-investigative-strategy-under-fire.

83 De Vos, supra note 81, at 1014.

84 Ibid.

85 Susana SáCouto \& Katherine Cleary Thompson, 'Investigative Management, Strategies, and Techniques of the ICC's OTP', in Stahn, supra note 59, at 338. The OTP's recent "Basic Size" document suggests that the Office intends to dedicate more of its budget to investigation, such as by adding 25 new investigators. See ICC Office of the Prosecutor, Report of the Court on the Basic Size of the Office of the Prosecutor, ICC-ASP/14/21 (2015), at § 29 (Basic Size Document). The contemplated increases, however, are unlikely to fundamentally transform the nature of the OTP's investigations. 
conducting investigations'. ${ }^{86}$ De Vos argues that the brevity of field missions - an average of 10 days in the DRC situation - makes it difficult for investigators 'to even interview witnesses, much less to develop the sort of long-term connections that amore sustained field presence would enable'. ${ }^{87}$ And Kambale has argued, combining the two critiques, that the DRC investigative teams were simply 'too undersized and too short-term to generate good analysis of the intricately entangled criminal activities' in the Ituri area. Indeed, he believes that the OTP's failure to bring charges against DRC suspects more important than Lubanga was 'a direct result of the prosecutor's strategy of conducting quick investigations with the lowest cost possible'. ${ }^{88}$

It is important not to overstate national investigative resources. But even the most resource-poor states - including those that have recently emerged from conflict - will generally have greater resources than the ICC. ${ }^{89}$ National investigators also obviously have the kind of permanent in-country investigative presence that the ICC does not. In almost every situation, therefore, a state will be able to conduct a more intensive and wider-ranging investigation than the OTP. ${ }^{90}$

Nor is that all. Effective investigation is not simply a function of resources; it also requires investigators to have a sound understanding of the local situation. And here, too, states have an inherent advantage over the ICC:

Unlike international tribunals, domestic prosecutors do not need to gather information to develop their knowledge and understanding of the political, military and security structures of the parties to the conflicts. Likewise, unlike international counterparts, local

86 Human Rights Watch, 'Letter to the Executive Committee of the Prosecutor', 15 September 2008, available online at http://www.article423.org/Secret\%20Human\%20Rights\%20Watch\%20Letter.pdf

87 De Vos, supra note 81, at 1016.

88 P. Kambale, 'The ICC and Lubanga: Missed Opportunities', SSRC Forums: African Futures, 16 March 2012, available online at www.forums.ssrc.org/african-futures/2012/03/16/african-futures-iccmissed-opportunities.

89 M. Tedeschini, 'Complementarity in Practice: the ICC's Inconsistent Approach in the Gaddafi and Al-Senussi Admissibility Decisions', 7 Amsterdam Legal Forum (2015) 76-97, at 78; see also Basic Size Document, supra note 85 , at $\S 44$ (noting that 'the ICC has had to investigate crimes comparable to the worst crimes to take place in domestic jurisdictions, but has had far fewer resources than those domestic investigations').

90 De Vos, supra note 81, at 1014. 
prosecutors do not need to acquire knowledge of the historical and political background to the conflict. Nor is there a need to build knowledge on the area of the conflict. Much less, if any, translation and interpretation are required. ${ }^{91}$

This domestic advantage has been particularly pronounced at the ICC. As of 2013, not even one OTP investigator had been a national of the state he or she was investigating. ${ }^{92}$ Even worse, unlike its ad hoc counterparts, the 0TP had not hired a single country expert either full-time or part-time, ${ }^{93}$ choosing instead to rely exclusively on volunteer local intermediaries. ${ }^{94}$ The OTP's lack of country-specific knowledge came back to haunt it in the DRC: according to one intermediary from Ituri, the OTP 'faced difficulties in assessing places and was unfamiliar with the socio-political context... did not understand the complicated war-time alliances, and did not grasp the subtleties of 'who was close to who' in a toxic environment nor 'who could do what". ${ }^{95}$ Even the use of local intermediaries did not help, because they were largely unsupervised and were never included in OTP strategising. ${ }^{96}$

Because of their generally superior investigative resources and greater local knowledge, national prosecutors are likely to identify provable conduct than their international counterparts. The Appeals Chamber's interpretation of Art. 17, however, renders their superior knowledge meaningless: even if prosecuting substantially the same conduct as the OTP will be much more likely to result in an acquittal, any attempt to prosecute different conduct will automatically make a case admissible.

\section{b. Charges}

For all the reasons discussed above, it is counterproductive to require a state to prosecute the same conduct as the OTP when it could prosecute different conduct more effectively. In some situations, the more easily proven conduct might actually involve the same charges, such as the war crime of murder the state simply bases the charges on different incidents than the OTP. But in other situations the more easily proven charge may be based on different

91 V. Tochilovsky, 'Post-Conflict Criminal Justice: Practical and Policy Considerations' in M. Bergsmo (ed.), Criteria for Prioritizing and Selecting Core International Crimes Cases (Torkel Opsahl Academic Publisher, $2 \mathrm{~d}$ ed., 2010) 237, at 238.

${ }_{92}$ De Vos, supra note 81, at 1019.

93 Ibid. at 1020.

94 Ibid. at 1021.

95 Quoted in ibid. at 1020.

${ }^{96}$ Kambale, supra note 88. 
conduct: the OTP charges the suspect with the war crime of murder; the state charges the suspect with the war crime of rape - or even with 'ordinary' rape, now that it's clear states do not have to charge international crimes as international crimes.

It is also likely, of course, that there are some situations in which a state can prosecute the same conduct as the OTP no less effectively than it could prosecute different conduct. It is tempting to argue that the SSC requirement should apply in that situation. But doing so overlooks a critical point: namely, that the selection of charges is driven by more than the availability of evidence. There may be many legitimate non-evidentiary reasons - reasons that do not exhibit unwillingness - for a state to prosecute a suspect on charges involving different conduct.

Most obviously, national prosecutors might rationally conclude that popular or elite opposition makes it too politically dangerous to mirror the OTP's case. In such a situation, the SSC requirement forces the state to either cede control of the case to the ICC or prosecute the same conduct and risk political destabilization - an easy choice. Eliminate the SSC requirement, however, and that Hobson's choice disappears: national prosecutors can prosecute the suspect on charges involving different and less controversial conduct, thereby avoiding destabilization while still protecting state sovereignty.

To be sure, elites or the populace may oppose prosecuting certain suspects a popular Head of State, a war-hero General - regardless of the charges against them. But that will not always be the case. As Mark Osiel has noted, for example, prosecutions of high-ranking government officials for actions during the Dirty War in Latin America and the Arab Spring in the Middle East have been far more successful 'when focused more on charges of financial corruption (always indefensible, in voters' eyes) than atrocities (sometimes so, depending on whose terrorists, ours or theirs, get the garrote)'.97

A state might also rationally prefer to prosecute different conduct than the OTP because of the interests of victims. There is no guarantee that an OTP prosecution will better align with victim preferences than a national prosecution; in fact, given the state's vastly superior local knowledge, the opposite is more likely to be true. The Lubanga case is a good example: victims groups were outraged by the OTP's refusal to charge Lubanga with crimes involving sexual violence. ${ }^{98}$ Given the ICC's emphasis on victims'

97 M.J. Osiel, 'The Demise of International Criminal Law', Humanity (June 2014) 1 , at 5, available online at http://humanityjournal.org/blog/thedemise-of-international-criminal-law/.

98 See J. McBride, The War Crime of Child Soldier Recruitment (Springer, 2013), at 157. 
rights, ${ }^{99}$ it makes no sense in such a situation - ceteris paribus - to prevent the state from prosecuting the conduct the victims have identified as the most important. Yet that is precisely what the SSC requirement does.

Finally, eliminating the SSC requirement would permit states to prosecute more serious charges than the OTP. There is no guarantee that the OTP will always pursue the most serious possible charges against a suspect; on the contrary, given its investigative limits relative to states, it may well have no choice but to pursue lesser charges. That was clearly the case in Lubanga, where the OTP pre-empted national charges involving murder, illegal detention, and torture in order to prosecute Lubanga for enlisting and using child soldiers. ${ }^{100}$ And it was likely the case in Katanga, as well. In challenging admissibility, Katanga argued that the 'same conduct' test was inconsistent with the principle of complementarity in his case because he was facing much more serious crimes in the DRC than at the ICC - genocide vs. crimes against humanity and war crimes. The Pre-Trial Chamber and Appeals Chamber nevertheless affirmed the same-conduct test and deemed his case admissible. ${ }^{101}$

\section{c. Modes of Participation}

The SSC requirement might also require national prosecutors to pursue a mode of participation that is much more difficult to prove than a mode that would be available for different conduct. The most obvious example is command responsibility, which requires prosecutors to prove the crimes committed by the commander's subordinates, the commander's knowledge of those crimes, and the commander's effective control.102 International prosecutors normally rely on command responsibility when they cannot connect the suspect to international crimes more directly, so it is unlikely that a state could render a command-responsibility case inadmissible by using the same conduct to prove a different mode of participation. That problem would disappear, however, in the absence of the SSC requirement: national prosecutors would then have the option of focusing on different conduct that supports an easier-to-prove mode of participation - such as a crime that the suspect ordered instead of failed to prevent.

\section{d. Gap-Filling}

99 See, e.g., Art. 65(4) ICCSt.

100 Decision on the Prosecutor's Application for a Warrant of Arrest, Lubanga (ICC-01/04-01/06), Pre-Trial Chamber I, 10 Feb. 2006, § 33 (Lubanga Arrest Warrant).

101 See Stahn, Quasi-Primacy, supra note 59, at 233.

102 K.J. Heller, 'A Sentence-Based Theory of Complementarity', 53 Harvard International Law Journal (HILJ) (2012) 86-132, at 103. 
Similar considerations apply when the OTP prosecutes conduct that a state cannot prosecute because of a gap in its domestic criminal law. A number of states, for example, either lack a provision on command responsibility (Sudan ${ }^{103}$ ) or treat it as a substantive offence instead of as a mode of participation (Canada ${ }^{104}$ ). Similarly, some international crimes simply lack ordinary domestic crime counterparts. The crime against humanity of persecution and war crimes such as denying quarter and recruiting child soldiers are the most obvious examples. In such situations, unless the state has incorporated international crimes, the SSC requirement will render a case admissible no matter how genuinely the state wants to bring the suspect to justice. Once again, though, the problem would be solved by eliminating the SSC requirement: the state could then simply charge the suspect with crimes based on different conduct.

\section{Strategic Considerations}

The SSC requirement can also needlessly undermine sound national prosecutorial strategies. Consider a situation in which a state wants to prosecute a suspect for a small subset of the conduct underlying the OTP's charges. That is a realistic possibility in the Ongwen case, given the OTP's recent announcement that it intends to charge Ongwen with 70 counts of war crimes and crimes against humanity based on nearly a half-dozen different attacks. ${ }^{105}$ If Uganda had wanted to prosecute Ongwen itself, it may well have preferred to charge him with only a few of those attacks in order to simplify the prosecution, shorten the resulting trial, and conserve investigative, prosecutorial, and judicial resources. But would such a targeted national prosecution have satisfied the SSC requirement?

The answer, unfortunately, is unclear. In the Gaddafi case, the Appeals Chamber offered the following cryptic thoughts on the subject:

If there is a large overlap between the incidents under investigation, it may be clear that the State is investigating substantially the same conduct; if the overlap is smaller, depending upon the precise facts, it may be that the State is still investigating substantially the same conduct or that it is investigating only a very small part of the Prosecutor's case. For example, the incidents that it is investigating may, in fact, form the

103 Ibid. at 124.

$104 \mathrm{Ibid}$. at 116.

105 Case Information Sheet, Prosecutor v Dominic Ongwen (ICC-PIDS-CIS-UGA02-009/16_Eng), 10 Feb. 2016. 
crux of the Prosecutor's case and/or represent the most serious aspects of the case. Alternatively, they may be very minor when compared with the case as a whole. ${ }^{106}$

This statement appears to suggest that the SSC requirement permits a state to pursue a more targeted national case as long as it covers the 'crux' of the OTP's case - i.e., its 'most serious aspects'. But that standard is simply unworkable. What is the crux of the Ongwen case? How should the Court determine its 'most serious aspects'? It obviously could not ask the OTP - if the OTP wanted to ensure admissibility, it would simply identify conduct the state is not prosecuting as the 'crux' of its case - and the Court would have difficulty making that decision itself, given the near-impossibility of comparing the gravity of international crimes. ${ }^{107}$ Moreover, any attempt by the judges to identify the most serious aspects of the OTP's case would be difficult to reconcile with prosecutorial independence. ${ }^{108}$ The solution is thus obvious: eliminate the SSC requirement. In the absence of the requirement, a state would be free to conduct a targeted prosecution as long as its decision to do so did not reflect unwillingness.

The SSC requirement can also create the opposite problem: discouraging a state from pursuing a prosecution that is more ambitious than the OTP's. Again consider the Lubanga case: although the OTP prosecuted him only for the war crime of enlisting and using child soldiers, the DRC had arrested him on suspicion of murder, illegal detention, and torture. Had the DRC challenged admissibility, Lubanga's case would have been admissible, despite its much greater scope, simply because of the SSC requirement.

To be sure, the SSC requirement would not have been an insuperable obstacle in that situation: the DRC could always have added the child-soldiers charges to its national case. But there may well be situations in which a state wants to pursue a wider investigation that - for any of the reasons identified above - does not include the OTP's chosen conduct. There is no justification for using the SSC requirement to reject an admissibility challenge in such situations. Indeed, Judge Ušacka described that very possibility as 'perverse' in her Gaddafi dissent. ${ }^{109}$

\section{Capacity Building}

106 Gaddafi Appeals Judgment, supra note 56, § 72.

107 See generally A.M. Danner, 'Constructing a Hierarchy of Crimes in International Criminal Law', 87 Virginia Law Review (2001) 415-501.

108 See generally K.J. Heller, 'The Role of the International Prosecutor' in C. Romano et al. (eds.), Oxford Handbook of International Adjudication (Oxford University Press, 2014) 669-689.

109 Ušacka Gaddafi Dissent, supra note 5, § 55. 
Eliminating the SSC requirement would facilitate national capacity building. One reason is obvious: because the requirement is so restrictive and ICCcentric, permitting states to prosecute different conduct would significantly increase the number of cases that states could prosecute themselves, thereby requiring them to strengthen their investigative, prosecutorial, and judicial systems. ${ }^{110}$ But the capacity-building effect of genuine complementarity would not simply be the product of need: states that are given the primary authority to prosecute international crimes are much more likely to want to build national capacity than states that are left to feed on the ICC's crumbs. That is one of the critical lessons of the ICTY's move from sticks to carrots through the adoption of Rule 11bis, which had a profoundly transformative effect on Bosnia's criminal-justice system:

The stick of removing cases from Bosnian jurisdiction under Rules of the Road clearly did not suffice to impel fair trial domestically, but the carrot of transfer back to the domestic justice system did. Once the internationalist paradigm of the ICTY gave way to the need to devolve responsibility to the states, the proposed solution was the aforementioned War Crimes Chamber created within the State Court and while a prosecutorial Special Department for War Crimes formed inside the national Prosecutor's Office... [I]t would appear that, were it not for the ICTY Completion Strategy, national capacities such as those which are now in existence may never have been created'.111

To be sure, eliminating the SSC requirement would not magically convince all of the states under the ICC's watchful eye to become the next Bosnia. But if even a few of them were motivated to build domestic capacity by the prospect of not having their prosecutorial choices driven by the OTP, eliminating the SSC requirement would be more than worth it.

\section{State Cooperation}

110 Cf. Stahn, Quasi-Primacy, supra note 59, at 239 (noting that '[a] predominantly Hague-centred vision of complementarity... hinder[s] the growth of effective national jurisdictions willing and able to prosecute the crimes, especially in Africa').

111 P. McAuliffe, 'Bad Analogy: Why the Divergent Institutional Imperatives of the Ad Hoc Tribunals and the ICC Make the Lessons of Rule 11bis Inapplicable to the ICC's Complementarity Regime', 11 International Organizations Law Review (2014) 345-427, at 402-403. 
A much more state-centric principle of complementarity might also make states more willing to cooperate with the ICC. ${ }^{112}$ Because the Court lacks effective enforcement mechanisms, few if any OTP prosecutions will succeed without state cooperation. ${ }^{113}$ Such cooperation is always unlikely when a state loses an admissibility challenge, as the Kenyatta debacle indicates. But it is reasonable to assume that cooperation is even less likely when a state believes that its domestic accountability processes are being unfairly micromanaged by the OTP. Chehtman, for example, ascribes the generally hostile relationship between the OTP and Colombia to the latter's resentment of the former's patronising and seemingly-endless 'observation' of Colombian legal processes. ${ }^{114}$ Creating a more state-centric complementarity regime by eliminating the SSC requirement would thus presumably encourage greater cooperation by states, at least at the margins.

\section{National Resources}

Greater flexibility in case-selection at the national level would have the additional benefit of conserving national investigative, prosecutorial, and judicial resources. In practice, the SSC requirement means that case selection is driven by the OTP, not by national prosecutors. Yet, for all the reasons discussed above, national prosecutors are far better equipped than the OTP to make intelligent decisions concerning which conduct can be most efficiently investigated and which charges can be most easily proven. The ability to pursue targeted prosecutions is particularly critical in this regard. States emerging from conflict often suffer from operational capacity problems and a large backlog of cases. ${ }^{115}$ Forcing such a state to mirror a sprawling OTP prosecution such as Ongwen's will simply exacerbate those problems, whereas allowing that state to pursue smaller prosecutions - even ones based on different conduct that the state determines can be more easily investigated and prosecuted - would minimise them.

112 A. Whiting, 'Dynamic Investigative Practice at the International Criminal Court', 76 Law and Contemporary Problems (2013) 163-189, at 183.

113 See, e.g., ibid., 183 (noting that, in practice, the Court has little recourse if states do not find it in their own interest to cooperate... and are not pressured by other actors in the international community who have the ability to exert pressure').

114 A. Chehtman, 'Developing Local Capacity for War Crimes Trials: Insights from $\mathrm{BiH}$, Sierra Leone, and Colombia', 49 Stanford International Law Journal (2013) 297-329, at 326.

115 I. Utmelidze, 'The Time and Resources Required by Criminal Justice for Atrocities and De Facto Capacity to Process Large Backlogs of Core International Crimes Cases: The Limits of Prosecutorial Discretion and Independence' in Bergsmo, supra note 91, at 188. 


\section{ICC Resources}

For similar reasons, eliminating the SSC requirement would conserve the ICC's limited resources. Given the Court's 'finite capacities', it is imperative to get the principle of complementarity right - 'every case pursued at the expense of domestic jurisdiction is also pursued at the expense of another potential ICC prosecution'.116 There is thus no justification whatsoever for permitting the OTP to pre-empt a genuine national prosecution simply because the state has decided to focus on different conduct. The admissibility of Simone Gbagbo's case is a perfect illustration: given that she is already facing 20 years in prison - six years longer than the ICC's longest sentence to date - what does the ICC possibly have to gain from (re-)prosecuting her?

\section{Rationales for the SSC Requirement}

The SSC requirement, in short, imposes very significant costs on both states and the ICC. Those costs might be acceptable if there was a convincing rationale for maintaining the requirement. But there isn't one. Some possible rationales have already been considered and rejected, such as that the SSC requirement maximises the likelihood of conviction, better reflects the interests of victims, or ensures that the suspect stands trial for his or her most serious conduct. Indeed, now that the Appeals Chamber has made clear that states are free to prosecute international crimes as ordinary domestic crimes, the only question is whether a state's selection of conduct exhibits an unwillingness to genuinely investigate or prosecute. And that issue is analytically distinct from whether the state is 'active' with regard to the OTP's case, as the Appeals Chamber itself has insisted.

There are, then, only two possible objections to eliminating the SSC requirement. The first is avowedly positivist: namely, that the SSC requirement is an integral part of the Rome Statute. There are two problems with that argument. To begin with, as explained above, the textually defensible test is 'same conduct', not 'substantially the same conduct'. So the judges have already taken pragmatic liberty with the Rome Statute in order to ensure that the principle of complementarity is not too restrictive. Moreover, the objection does not actually provide a substantive defence of the SSC requirement. It simply points out that eliminating it would likely require amending the Rome Statute.

The second objection, which has been advanced in a thoughtful article by Darryl Robinson, is more serious: that it is unnecessary to eliminate the SSC requirement, because '[t]he Rome Statute already provides solutions to the

116 Megrét \& Samson, supra note 15, at 580. 
scenario where a state wishes to prosecute a person for a different crime'.117 He identifies three such solutions: (1) Art. 94(1), which provides that ' $\mathrm{i}] \mathrm{f}$ the immediate execution of a request would interfere with an ongoing investigation or prosecution of a case different from that to which the request relates, the requested State may postpone the execution of the request for a period of time agreed upon with the Court'; (2) Art. 89(4), which provides that '[i]f the person sought is being proceeded against or is serving a sentence in the requested State for a crime different from that for which surrender to the Court is sought, the requested State, after making its decision to grant the request, shall consult with the Court'; and (3) Art. $53(2)(c)$, which permits the OTP to decline to prosecute an otherwiseadmissible case if doing so 'is not in the interests of justice, taking into account all the circumstances, including the gravity of the crime, the interests of victims and the age or infirmity of the alleged perpetrator, and his or her role in the alleged crime'.

None of these provisions, however, is an adequate substitute for eliminating the SSC requirement. Art. 94(1) can be quickly dismissed: the Pre-Trial Chamber specifically held in Gaddafi that it applies only to cooperation requests other than surrender, because Art. 89(4) 'is a lex specialis provision that specifically relates to surrender requests'.118 The Appeals Chamber has not addressed that issue, but it is unlikely it would disagree with the PTC. As the PTC noted, its interpretation of Art. 94(1) is 'supported by both the drafting history and learned commentators who have examined the issue'. ${ }^{119}$

If Art. 89(4) required the ICC to defer to a genuine national investigation or prosecution involving different conduct, it might be an adequate substitute for eliminating the SSC requirement. But that is almost certainly not the case. First, Art. 89(4) is directed at states, not at the Court itself - suggesting that the provision is intended to limit, not recognise, the freedom of states to pursue different-conduct proceedings. Second, the provision requires a state to agree to surrender the suspect before consulting with the Court - an unusual procedural requirement if a state has an absolute right to proceed with a different-conduct prosecution despite a competing surrender request. Third, unlike Art. 94(1), Art. 89(4) does not even mention the possibility of postponing the ICC prosecution following consultation - a contrast

117 D. Robinson, 'Three Theories of Complementarity: Charge, Sentence, or Process?', 53 HIJL Online (2012) 165-182, at 166; see also Konforta \& Vajda, supra note 52, at 17 (making a similar argument regarding Art. 94(1) ICCSt and Art. 89(4) ICCSt).

118 Decision on Libya's Submissions Regarding the Arrest of Saif Al-Islam Gaddafi, Gaddafi and Al-Senussi (ICC-01/11-01/11), Pre-Trial Chamber I, 7 Mar. 2012, § 15.

119 Ibid. 
emphasised by the Pre-Trial Chamber in Gaddafi. ${ }^{120}$ Fourth, and finally, a hard deferral requirement would mean that the Rome Statute actually makes it easier for a state to pursue a proceeding based on different conduct than a proceeding on the same conduct, which makes no sense.

At best, then, Art. 89(4) permits but does not require the ICC to defer to a national proceeding that is based on different conduct. That possibility hardly justifies maintaining the SSC requirement; after all, the point of eliminating the requirement is precisely to ensure that a state's right to conduct a competing investigation or prosecution is limited solely by its willingness to bring a suspect to justice. Requiring a state to convince the Court to defer to a national proceeding is still primacy instead of complementarity - especially given that Art. 89(4) does not specify the criteria the Court is supposed to use to make the deferral decision.

That leaves Art. 53(2)(c). The problem with arguing that the interests of justice' provision makes it unnecessary to eliminate the SSC requirement is obvious: the provision empowers only the OTP to decline to prosecute a suspect. The Pre-Trial Chamber does not have that power: although the PTC can order the OTP to prosecute a case it doesn't want to pursue because of the interests of justice, it cannot prevent the OTP from prosecuting a case it does want to pursue. That asymmetry follows ineluctably from Article 53(3)(b) of the Rome Statute. ${ }^{121}$ The 'interests of justice' provision is thus even less of a substitute for eliminating the SSC requirement than Art. 89(4), because it leaves the fate of a national proceeding based on different conduct solely in the hands of the OTP, which has shown little interest in moving away from a narrow understanding of the requirement as a matter of prosecutorial policy - as the Simone Gbagbo case dramatically illustrates.

Unless the SSC requirement is eliminated, in short, a state that wants to prosecute an ICC suspect for conduct unrelated to the OTP's case will normally have only one option: to wait until the ICC proceedings conclude. That may be practically possible when the suspect is either acquitted by the ICC (such as Ngudjolo) or serves out his or her sentence (Katanga). But even then the state will be forced to wait for years before prosecuting: Ngudjolo was detained by the ICC for nearly five years before he was acquitted, and Katanga was in custody for nearly nine years before the ICC transferred him

\footnotetext{
120 Ibid.

121 Art. 53(3)(b) ICCSt ('In addition, the Pre-Trial Chamber may, on its own initiative, review a decision of the Prosecutor not to proceed if it is based solely on paragraph 1 (c) or 2 (c). In such a case, the decision of the Prosecutor shall be effective only if confirmed by the Pre-Trial Chamber'.).
} 
to the DRC. ${ }^{122}$ A better example of how the SSC requirement reflects primacy instead of complementarity is difficult to imagine.

\section{Unwillingness}

In exploring the problems with the SSC requirement, this Article has assumed that the state challenging admissibility genuinely desires to bring a suspect to justice. That assumption is not unrealistic; it is impossible to argue that the mere act of investigating or prosecuting different conduct than the OTP indicates that the state is trying to shield the suspect from criminal responsibility. Lubanga's case is a good example, given that the DRC intended to prosecute him for much more serious conduct than recruiting and using child soldiers.

That said, in the absence of the SSC requirement, some states would almost certainly use a different-conduct investigation or prosecution as a pretext to avoid holding a suspect accountable for his or her crimes. Sudan's decision to charge two intelligence officers suspected of involvement in a mass killing with looting instead of murder provides an instructive example. ${ }^{123}$ So there is no question that the Court would have to carefully scrutinise differentconduct proceedings to ensure that the state is, in fact, genuinely investigating or prosecuting.

But that is already the case. The ICC obviously cannot infer willingness from the mere fact that a national proceeding is based on the same conduct as the international proceeding; there are many ways to subvert an investigation or

122 The DRC does indeed intend to prosecute Katanga for different conduct. See AFP, 'DR Congo to prosecute militia leader Katanga, convicted by ICC', Mail Online, 18 Jan. 2016, available online at http://www.dailymail.co.uk/wires/afp/article-3404595/DR-Congoprosecute-militia-leader-Katanga-convicted-ICC.html. Such subsequent prosecutions are consistent with the Rome Statute's ne bis in idem provision, Art. 20. See Art. 20(2) ICCSt ('No person shall be tried by another court for a crime referred to in article 5 for which that person has already been convicted or acquitted by the Court'.).

${ }^{123}$ See Human Rights Watch, Lack of Conviction: The Special Criminal Court on the Events in Darfur (June 2006) at 13-14, available online at https://www.hrw.org/legacy/backgrounder/ij/sudan0606/sudan0606.pdf. 
prosecution that have nothing to do with the selection of conduct. ${ }^{124}$ Moreover, given that states are free to charge international crimes as ordinary domestic crimes, the Court is already facing the need to develop a reliable heuristic for comparing the gravity of specific domestic crimes with their corresponding international counterparts. In some situations, such comparisons will be unproblematic - charging a suspect with murder instead of the war crime of murder, for example, obviously does not qualify as unwillingness. But other comparisons will be more difficult, such as where a state charges a suspect with voluntary manslaughter instead of the crime against humanity of murder or with sexual assault instead of the war crime of rape.

There is no question that eliminating the SSC requirement would further complicate the ICC's unwillingness inquiry. When a national proceeding is based on the same conduct as the international proceeding, the Court must only ensure that neither the charged crime nor the mechanics of the state's investigation and prosecution indicate that the state is trying to shield the suspect from criminal responsibility. In the absence of the SSC requirement, the Court would have to scrutinise the state's selection of conduct, as well. At the ends of the willingness spectrum, that assessment would be no more problematic than the international crime/domestic crime assessment: a state that charged looting when the OTP charged the war crime of murder would be clearly unwilling to genuinely prosecute, while a state that charged rape when the OTP charged the war crime of recruiting child soldiers would be just as clearly willing. But there is no question that situations in the middle would be difficult for the Court to assess - such as the Dirty War and Arab Spring cases mentioned above, where states prosecuted economic misconduct instead of mass atrocities.

Such added complexity would be a genuine cost of eliminating the SSC requirement, and it needs to be openly acknowledged. But the issue is one of degree, not of kind, given that states are not required to prosecute international-crimes as international crimes. If the ICC can compare an international crime to an ordinary domestic crime that is based on the same conduct, it can surely compare an international crime to an ordinary domestic crime that is based on different conduct. In both situations the question would be the same: does the state's decision to deviate from the OTP's case indicate that it is trying to shield the suspect from criminal responsibility, or does it simply reflect the state's good-faith determination that prosecuting a different crime - whether based on the same or different conduct - will be more likely to end in conviction?

124 C. Stahn, 'One Step Forward, Two Steps Back? Second Thoughts on a "Sentence-Based" Theory of Complementarity', 53 HILJ Online (2012) 183196 , at 188. 
Moreover, as I have argued elsewhere, the ICC could assess willingness in both situations by comparing the sentence the suspect would likely receive in the international proceeding to the sentence he or she would likely receive or has already received - in the national proceeding. ${ }^{125}$ In my view, if the anticipated or actual national sentence would be equal to or longer than the anticipated international sentence (with some margin of appreciation), the Court could not credibly infer that the state was trying to shield the suspect from justice. And that would be true regardless of whether the ordinary domestic crime was based on the same or different conduct. ${ }^{126}$ Consider the same-conduct situation mentioned above: where a state charges a suspect with manslaughter instead of the war crime of murder. In the absence of process concerns, if voluntary manslaughter in that state normally results in a sentence of 30 years or more - the maximum sentence at the ICC in the absence of aggravating circumstances ${ }^{127}$ - that state could not credibly be considered unwilling to genuinely prosecute. Or consider a different-conduct situation such as Simone Gbagbo's, where the national prosecution actually resulted in a sentence considerably longer than either of the sentences imposed by the ICC. Under the circumstances, and taking into account the sentencing practices of other international tribunals, ${ }^{128}$ it is difficult to conclude that the Ivorian prosecution was designed to shield Gbagbo from justice.

\section{CONCLUSION}

The ICC is struggling. After 13 years of life, it has convicted three defendants (Lubanga, Katanga, and Bemba), acquitted one (Ngudjolo), refused to confirm charges against four suspects (Abu Garda, Mbarushimana, Kosgey, and Ali), and temporarily postponed the confirmation hearing for a fifth because of lack of evidence (Laurent Gbagbo). The OTP has also had to dismiss charges against two defendants (Kenyatta and Muthaura) and suspend investigation into an entire situation (Sudan) because the targeted states refused to cooperate with it. ${ }^{129}$

125 Heller, supra note 102 , at 109-114.

126 There is, of course, a third possibility: the state charges the suspect with the same international crime as the OTP, but focuses on different conduct. For example, a state might focus on different rapes than the OTP but characterize those rapes in the same way - as a war crime or as a crime against humanity. The only unwillingness issue in such a situation would be the legitimacy of the process: whether the state was genuinely trying to convict the suspect.

127 Art. 77(1)(a) ICCSt.

128 See Heller, supra note 102, at 120-123.

${ }^{129}$ See De Vos, supra note 81, at 1010-1011 (collecting cites). 
It would be foolish to attribute primary responsibility for the ICC's problems to the Court's myopic approach to the principle of complementarity. But there is also no question that complementarity issues have played an important role in its struggles, as demonstrated by the contentious admissibility battles between the OTP and Kenya, Libya, and Côte d'Ivoire. Rightly or wrongly, far too many states have become convinced that the ICC is 'an inwardly focused court whose primary concern is not the well-being of societies recovering from mass atrocities, but instead the maintenance of a docket that will maximise the Court's own visibility and prestige'.130

It is against the backdrop of these struggles that this Article defends radical complementarity - the idea that as long as a state is making a genuine effort to bring a suspect to justice, the ICC should find his or her case inadmissible regardless of the conduct the state investigates or the prosecutorial strategy the state pursues. For all of the reasons discussed in this Article, it is impossible to justify permitting the Court to pre-empt cases like Simone Gbagbo's simply because the state has second-guessed the OTP's selection of conduct. Indeed, although it is impossible to prove a counterfactual, it seems reasonable to assume that even the Kenyan government might have been more cooperative if the Court had bent over backwards (as it did in the Libyan situation) to avoid finding the Kenya cases admissible.

The best solution to the ICC's complementarity crisis is the one proposed in this Article: relaxing the 'same person' requirement to permit pyramidal (and similar) investigative strategies and eliminating the 'substantially the same conduct' requirement as a matter of law. The judges themselves could enact the first reform; as discussed earlier, the Appeals Chamber's 'concrete and progressive investigative steps' standard has no basis in the Rome Statute. But the second might require amending the Rome Statute, because the Statute at least arguably requires the 'same conduct' test,131 if not the 'substantially' qualifier.

Amending the Rome Statute is notoriously difficult. So if removing the 'same conduct' requirement is not possible, the Court should at least consider adopting one or more of the alternatives identified by scholars who are aware of the SSC requirement's negative consequences. Judge Ušacka has recommended that the judges relax the requirement much more than the Appeals Chamber has already done; in her view, although there needs to be a 'nexus between the conduct being investigated and prosecuted domestically

130 A. Greenawalt, 'Complementarity in Crisis: Uganda, Alternative Justice, and the International Criminal Court', 50 Virginia Journal of International Law (2009) 107-162, at 160.

131 See Rastan, supra note 51, at 437-440. 
and that before the Court, this "conduct" and any crimes investigated or prosecuted in relation thereto do not need to cover all of the same material and mental elements of the crimes before the Court and also does not need to include the same acts attributed to an individual under suspicion'.132 Stahn has proposed that the Court adopt greater 'qualified deference' to national proceedings, whether by giving a state more time to build a case between an admissibility challenge and the Court's adjudication of that challenge or by adopting a 'conditional admissibility' regime in which the Court sets investigative and prosecutorial benchmarks for a state that has challenged admissibility and adjudicates the challenge only if the state fails to meet those benchmarks. ${ }^{133}$ And Robinson has proposed that the Assembly of States amend the Rules of Procedure and Evidence to juridify the consultation and sequencing process, requiring the Court to prioritise a genuine national proceeding based on different conduct. ${ }^{134}$

Any of these proposals would be a considerable improvement over the counterproductive status quo. But they still do not go far enough. The ICC will never function effectively - much less fulfill its lofty aspirations - until it has fundamentally reconsidered its relationship with national criminaljustice systems. Put simply, the Court's complementarity crisis calls for nothing less than radical complementarity.

132 Ušacka Gaddafi Dissent, supra note 5, § 59.

133 Stahn, Quasi-Primacy, supra note 59, at 253-254.

134 Robinson, supra note 117, at 181-182. 